\title{
应对突发性重大疫情, 全球性合作正在兴起
}

\author{
马中良 ${ }^{(1)}$ 高福 ${ }^{(2) *}$ \\ (1) 上海大学生命科学学院, 上海 200444; \\ (2) 中国科学院微生物研究所, 北京 100101 \\ *联系人, E-mail: gaof@im.ac.cn
}

近几年来, 信息的畅通使得不同地方的重大疫情牟动 着全球每个角落的人们: 中东呼吸综合征 (Middle East Respiratory Syndrome, MERS)、埃博拉病毒(Ebola)、禽流感, 还有一些人们已经熟悉的艾滋病 $(\mathrm{HIV})$ 、乙肝病毒 $(\mathrm{HBV})$ 等. 人类社会怎么了, 会变得更好吗? 我们应该怎么面对 这些疫情?

\section{1 目前的形势}

2015 年诺贝尔生理学或医学奖(Nobel Prize in Physiology or Medicine)授予中国科学家屠呦呦及另外两名来自 日本、瑞典的科学家, 以表彰他们在防治重大疾病——寄 生虫引起的疾病中的突出贡献. 诺贝尔奖的颁布体现了科 学界对重大疾病的关注. 近年来一些新发传染病引起国际 社会的重视. 自 2014 年以来, 塞拉利昂、利比里亚和几内 亚等西非国家 Ebola 病毒肆虐, 世界卫生组织(WHO)全力 协调, 阻止和预防病毒扩散. 另外, MERS 的出现也引起了 局部地区的恐慌. 在 WHO 各成员国的通力协作下, MERS 仅仅在中东和韩国出现少数病例. 因此世界各国已经认识 到, 防止重大传染病或新发传染病已经不是一个国家能解 决的事, WHO 呼叮国际合作, 科技发达国家及发达国家应 承担更大的责任.

\section{2 中国在重大传染病领域的突破}

2015 年美国和加拿大的 Ebola 病毒的疫苗已经开始应 用到西非国家. 中国农业科学院哈尔滨兽医研究所、中国 科学院病原微生物与免疫学重点实验室等对重大传染病 进行了较为系统的研究. 研究人员对禽流感病毒的分子机 理、流行病学以及病毒跨种间传播的研究中取得重要进展 ${ }^{[1,2]}$. 中国科学院微生物研究所对流感病毒、非典(SARS)、 MERS 及 Ebola 等病毒的致病机理及病毒的传播机理进行 了深人研究 ${ }^{[3 \sim 7]}$, 其中对 Ebola 病毒致病机理的研究于 2016 年取得重大进展, 相关结果发表在 Cell 上 $^{[8]}$. 他们的研究 为防治这些病毒提供了条件. 曹雪涛研究团队则从病毒致 病的免疫学机理中取得突破, 并且探讨非编码 RNA 在免 疫调控中的作用 ${ }^{[011]}$. 中国科学家在基础研究中成绩显著, 尤其高福研究团队及陈化兰研究团队的研究给传染性疾病
的防控提高了理论依据, 比如禽流感的传播可能来自中间 候鸟的迁徙或者活禽, 因此建议关闭或暂停一些大型活禽 的交易市场.

中国科学家的成绩引起了全世界的关注, 这些工作为 进一步的研究奠定了基础, 也为人类战胜重大疾病增强了 信心.

\section{3 合作成为必然}

中国在经历了 SARS 后, 对突发性传染病已经积累了 丰富的经验. Ebola 病毒在非洲爆发后, 协助 WHO 以西非 相关国家，中国主要做了以下工作:

(i ) 教育培训. 中国科学家为西非国家培训公共卫 生师资队伍, 为当地留下一支不带走的防治传染病的队伍. 培训对象为医务人员、基层管理者、社区领袖或政府工作 人员、社区卫生工作者和志愿者等，在为期 6 个月的时间 里, 中国为西非国家培训公共卫生师资约 1 万人. 培训内 容涉及 Ebola 流行特点、中国应对传染性疾病的经验、WHO 防控策略和措施、病例管理、密切接触者追踪和感染控制、 健康教育、污染环境和物品的无害化处理等.

(ii) 硬件保障. 中国政府援建利比里亚诊疗中心, 为 塞拉利昂建成移动生物安全实验室 ( $\mathrm{P} 3$ 级别), 固定 $\mathrm{P} 3$ 实验室.

(iii) 人员配备. 中国政府自 2014 年 4 9 月先后组织 实施了 3 轮援助举措, 向 13 个非洲国家提供了防护救治的 物资、食品及现汇援助, 派遣了公共卫生专家组和医疗队. 据统计, 中国政府向塞拉利昂、利比里亚和几内亚等西非疫 区派出医疗专家、公共卫生专家、实验室检测人员等共 600 余人次.

中国政府及科学家的工作举世瞩目, 并且受到 WHO 总干事陈冯富珍的高度赞扬.

\section{4 新的合作模式启动一一美高级别科研合作}

2015 年 9 月底, 中国科学院和美国科学院的科学家在 北京中国科学院微生物研究所首次召开双边合作研讨会. 会议的主题是关于面对突发传染病、实验室安全和全球健 康安全挑战 (CAS-NAS Workshop on the Challenges of Emerging Infections, Laboratory Safety, and Global Health 
Security). 会议主要在 7 个方面进行交流: (1) 安全-保证规则 - 进展 (The“Safety-Security-Regulation-Progress”); (2) 流感(Infuenza); (3) 埃博拉病毒及其他(Ebola and beyond); (4) 中东呼吸综合征; (5) 基因功能研究(Gain of Function Research); (6) 高污染性实验室方面(High-Containment Labs: Safe, Secure, Productive, and Sustainable); (7) 提高合作领 域的圆桌讨论 (Roundtable discussion and Areas for Enhanced Cooperation). 中国科学院副院长张亚平教授致开 幕词. 美国科学院由副院长 Diane Griffin 教授领衔, 中方 参加的科学家主要来自中国疾病预防控制中心 (CDC)、军 事医学科学院及中国科学院微生物研究所. 笔者主要就生 命科学技术发展与生命伦理方面阐述观点. 目前科学家及 公众对该方面越来越关心, 而世界各国在生命伦理方面的 差异也比较明显：比如对待编辑胚胎基因的问题上 ${ }^{[12,13]}$, 西方国家注重尊重生命的本身, 而东方国家强调拯救生命 及生命的延续, 因此沟通交流更显重要. 双方在各个方面 进行了广泛的交流, 初步确定在科技人员交流及培训方面 展开切实可行的合作以及在重大疾病信息交流方面进行 更深层次的交流. 会议决定, 中美科学家的这种交流将持 续进行, 不久的将来会在美国召开交流会议, 形成交替主 持的传统.

根据中美经验以及 WHO 的预防措施, 目前应对防控 传染病, 主要应注意: 保护生态环境; 关注 “贫穷” 病、关注
非洲; 充分发挥政府调控能力; 研发有效的抗传染病手段, 疫苗、抗体、药物等.

\section{5 结语: 对未来的思考}

追溯以往，黑死病(Black death)、天花(Small pox)、 1918 大流感等均对人类文明及人口增长造成了重大影响. 在完成西非 Ebola 疫区的任务后, 中国科学院院士、中国 $\mathrm{CDC}$ 副主任高福研究员在 Science 发表了题为“On the ground in Sierra Leone”的评论 ${ }^{[14]}$, 呼吁青年科学家们共同 努力, 面对这些威胁人类的病毒.

传染性疾病对人类文明的破坏是显而易见的，人类开 始思索人类行为的变化与疾病的关系. 比如, 禽流感和 MERS 等是由于人类接触了中间宿主候鸟、骆驼等引起的 疾病; 而 1910 年在东北出现的肺鼠疫, 也是由于人类捕杀 当时的皮毛供应者一旱獭, 最后在伍连德博士的带领下 扑灭 ${ }^{[15]}$. 因此, 人类在向大自然探索的时候，应该考虑如 何避免出现这样的悲剧.

在本文的撰写过程中，另一种病毒一一寨卡病毒(Zika virus)开始在南美曼延. WHO 近日宣布，该病毒可能会引 起新生儿小头症状，警告当地育龄妇女防止传播该病毒的 蚊子叮咬. WHO 已经宣告寨卡病毒的蔓延为突发公共事件, 各个国家应积极合作统一行动. 因此, 开展国际合作对于 目前以及将来的传染病防治等显得尤为重要. 博士、施一博士在写作中提供的帮助. 感谢上海大学通识课程生命伦理学.

\section{推葆阅读文献}

1 Chen H. H5N1 avian influenza in China. Sci China Ser C-Life Sci, 2009, 52: 419-427

2 Zhang Y, Zhang Q, Kong H, et al. H5N1 hybrid viruses bearing 2009/H1N1 virus genes transmit in guinea pigs by respiratory droplet. Science, 2013, 340:1459-1463

3 Song H, Qi J, Khedri Z, et al. An open receptor-binding cavity of hemagglutinin-esterase-fusion glycoprotein from newly-identified influenza D virus: Basis for its broad cell tropism. PLoS Pathog, 2016, 12: e1005411

4 Cui L, Liu D, Shi W, et al. Dynamic reassortments and genetic heterogeneity of the human-infecting influenza A (H7N9) virus. Nat Commun, 2014, 5: 3142

5 Lu G, Hu Y, Wang Q, et al. Molecular basis of binding between novel human coronavirus MERS-CoV and its receptor CD26. Nature, 2013, 500: 227-231

6 Zhang W, Shi Y, Lu X, et al. An airborne transmissible avian influenza H5 hemagglutinin seen at the atomic level. Science, 2013, 340: 1463-1467

7 Liu D, Shi W, Shi Y, et al. Origin and diversity of novel avian influenza A H7N9 viruses causing human infection: phylogenetic, structural, and coalescent analyses. Lancet, 2013, 381: 1926-1932

8 Wang H, Shi Y, Song J, et al. Ebola viral glycoprotein bound to its endosomal receptor niemann-pick C1. Cell, 2016, 164: 258-268

9 Zheng Q, Hou J, Zhou Y, et al. Siglec1 suppresses antiviral innate immune response by inducing TBK1 degradation via the ubiquitin ligase TRIM27. Cell Res, 2015, 25: 1121-136

10 Wang P, Xue Y, Han Y, et al. The STAT3-binding long noncoding RNA lnc-DC controls human dendritic cell differentiation. Science, 2014, 344: 310-313

11 Zheng Q, Hou J, Zhou Y, et al. Type I IFN-inducible downregulation of microRNA-27a feedback inhibits antiviral innate response by upregulating Siglec1/TRIM27. J Immunol, 2016, 196: 1317-1326

12 马中良, 袁晓君, 孙强玲. 当代生命伦理学一一生命科技发展与伦理学的碰撞. 上海: 上海大学出版社, 2015. 48-54

13 马中良. 灵丹妙药还是潘多拉的盒子?——篇Protein \& Cell 论文引发的争论. 科学通报, 2016, 61: 287-288

14 Gao G F,Feng Y. On the ground in Sierra Leone. Science, 2014, 346: 666

15 Ma Z L, Li Y L. Dr. Wu Lien Teh, plague fighter and father of the Chinese public health system. Protein Cell, 2016, doi: $10.1007 / \mathrm{s} 13238-015-0238-1$ 